\title{
Adventures of a Student at Iowa
}

\section{PHILIP D. JORDAN}

If there was beauty in the Iowa landscape in September 1923, I scarcely noticed it. Corn stalks, withered to brown, stood like scarecrows in fields, hogs rooted in pens, and, now and again, neat houses and dilapidated, unpainted barns flashed by. We were traveling in an old Dodge at 30 miles an hour, a speed which fretted my mother so that she kept nagging my father to slow down on "these awful dirt roads." The entire trip was something of a nightmare, a journey from Burlington, Iowa, to Iowa City, where I was to become a freshman in the state university.

The ride was less than pleasant not only because I was wedged between suitcases and cardboard boxes in the back seat, so that I could hardly see out unless I rose up, half crouching, but also because I was ambivalent about entering college. One moment I was glad. The next I was sad. I would reach out to grasp the dream of becoming educated and then retreat as if I were en route to the Fort Madison prison. I anticipated college life with eagerness, yet I dreaded to fail, for I knew if my freshman year were muffed there would be no second chance. Both my parents made this abundantly clear in no uncertain manner.

We bumped, jounced, and jolted along with clouds of dust from roads pulverized in summer and thick with sticky mud in wet weather, and the dust crowded through open windows--air conditioning was unknown in those days-until heat and dust made motoring anything but comfortable and relaxing. Yet, it being September, there was a sort of sensual zest teasing the hot air, although such an impression, being in the state of mind I was, may have been only imagination. Anyway, I recall it vividly.

It is curious how small events stick in one's mind and large ones escape memory. I, for example, do not recall clearly our arrival in Iowa City or how we finally located a roominghouse on Jefferson Street, but I will never forget the house or my cell of a room in which I unpacked 
and settled down uneasily after seeing my parents begin the return trip to Burlington. Had my mother and father known more of the place, they never would have left me there.

My new home, a two-story frame structure, was situated just north and across the street from what was then the University Hospital, for in 1923 practically all the major university buildings were on the east bank of the Iowa River, a stream which I always considered a piddling affair, having been born and raised in a community on the banks of the mighty Mississippi. When one entered the house through the front door, one immediately faced a pair of steep steps. To the right a door opened into the living quarters of my landlady, a crotchety old woman made that way no doubt by letting out rooms to generations of students. She was deaf and had a shrill voice, so that she sounded when she spoke like the cry of a jungle bird. To the left was the only rented room on the ground level. It, I learned, was occupied by a couple of nurses.

The second floor was divided into four rooms-two large ones facing the street, a bathroom, and one just large enough to accommodate a single bed, a straight, sturdy chair, a typewriter table which doubled as a study desk, and a chest of drawers which the landlady referred to as a beautiful "burro." It may indeed have been a handsome bureau in its prime, but the drawers were dried and twisted, so that each stuck tightly and took a mighty yank to open. Two pharmacy students occupied one of the front rooms, and two females from the Deep South, graduate students in psychology, lived in the other. They piled their room, floor to ceiling, with stacks of hometown newspapers. Cigarettes kept the place smoke filled. The pharmacists smuggled alcohol from the lab and devoted their leisure time to making gin, getting a snootfull, and, for the sheer joy of it, pummelling one another.

My only window faced east. The view was fascinating and quite unlike anything which Dean Robert E. Rienow spoke about in his lectures to freshmen. My window faced another window some 15 feet away. Actually, I saw a peep show, for my neighbors, who jeered and exposed themselves, were unwed, pregnant girls whom some state agency was quartering until they could be taken across Jefferson Street to the hospital for delivery. Had I been a freshman medic instead of a liberal arts frosh, I am confident I could have fulfilled most requirements in gross anatomy. There is little use in describing the poor girls' vulgarity, except to indicate that they possibly exceeded anything shown in XXX-rated movie theaters today, although I never have seen such films.

My main concern was books, not bosoms, and I buckled down to 


\title{
DOCUMEN'TS,
}

\author{
L EG I S L A T I V E A N D EX ECU'TIVE, \\ 328 \\ 44765 \\ of THE
}

\section{CONGRESS OF THE UNITED STATES,}

\begin{abstract}
FROM THE FIRST SEESION OF THE FOURTEENTH TO THE SECOND SESSION OF THE NINETEENTH CONGRESS, INCLUSIVE:

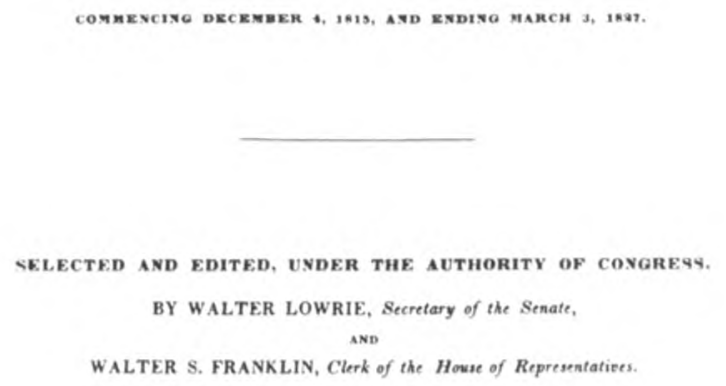

voLUMe 2

WASHINGTON:

PUBLISHED BY GALES AND SRATON.

1834.

". . he [Professor Ross Livingston] casulally mentioned the wonders to be found in the American State Papers. They were new to me. The next day I hotfooted to the library and in the document room discovered what livingston said was true. I hive always been indelited to him." 
work. I attended classes, did my homework, and took my meals in an unsavory, but reasonable, boardinghouse on Burlington Street. The building has long since been torn down. When I was not in class, I was in the library, and when I was not in the library, I was in my cell -frequently with the shades drawn-studying. Two fraternities rushed me, but I gave them the bum's rush because I knew I could not devote myself to my studies while living with "brothers" in a handsome structure and because I could not afford the cost of being a Greek with a fancy pin on my vest. I lived on a shoestring, and it never got any longer or stronger during the academic year. Don't forget that I also was living under a parental threat-"Either make it or get out"-although the admonition never was phrased so crudely.

From one viewpoint, I was a square, a drone, a bookworm. I never had a date, never attended a dance, never watched a football game. From another point of view, I was a youngster willing to sacrifice anything to make good-to secure a higher education. Of all the campus buildings, the library was my favorite. It was amazing, after reading through the limited stacks of my home town library, how many books and periodicals there were in the world! It was in the library that I received my greatest enjoyment and harvested the most learning. I carried books home in a cheap rucksack. I learned then, as I now know, that the library is the heart of any academic institution, although I do not believe I fully comprehended the treasures of a library until some years later when I returned to the University as a graduate student in history.

Although I carried five academic subjects-English Rhetoric, Speech Principles, French, Geology, and Modern European History-during my first year at Iowa, only two really proved both appealing and stimulating, yet I suppose all benefited me in one way or another. A slight, sprightly woman, Clara M. Daley, taught the history. Professor Walter R. Livingston spoke truly in later years when he characterized Miss Daley as a splendid lady and added that all freshmen students "thought she was a great teacher."1 My English instructor, a Mr. Moffet, was a departmental assistant. He certainly was not the teacher that Miss Daley was, but he was interested in the small section he managed and he did his best to encourage me to write. Fortunately, I still have the huge notebook I kept for Miss Daley and, equally fortunately, I kept all the themes I wrote for Moffet.

A background of Latin in high school plus excellent training in English received from Miss Ruth Melzian put me, I am sure, at a de-

1 The University of Iowa, Oral History Project, James Beilman interview with Dr. W. R. Livingston, Iowa City, November 4, 1976, University Archives.

[31] 
cided advantage over other students in Moffet's section. For one thing, I knew grammar. For another, I had learned to write about things I knew and to compose in simple prose without resorting to purple language and redundancy. I knew the value of the active voice and of strong verbs. I also knew the worth of a first draft, revised drafts, and finally the finished product. Most important of all, I learned in high school the value of self-discipline and how to study.

So, as a university freshman, I submitted papers about what I knew and not what I thought I knew. I wrote essays about a cross section of university life, about the peculiarities of professors, about living away from home, about scenes at the boardinghouse table. I set down the manners of the 15 boys and 20 girls who took meals with me and quoted their chattering conversation, told of their love affairs, and, of course, devoted space to the ever-present thick bread, mashed potatoes, and biscuits which may well have been hardtack that survived the Civil War. I wrote a paper on funny papers in Sunday newspapers and did another on O. Henry. Moffet marked all themes "excellent" and not a one received a grade less than A-. At semester's end I received a grade of $\mathrm{B} !$ Perhaps that was to remind me that "leer" is not spelled "lear."

Although I attended regularly and gave diligent attention to both French and Speech, I recall nothing about either, probably because both subjects were taught by assistants who, like some assistants then and now, did little more than go through the motions of instruction. To them, teaching freshmen was both a bore and a chore. Physical and historical geology was an entirely different matter.

Professor Arthur C. Trowbridge, a scholar and stimulating teacher, gave the general lectures in both courses. He fascinated me, for, growing up in Burlington, I knew something about brachiopods and crinoids and of the world-famous research of Charles Wachmuth and Frank Springer, who wrote the definitive work on the paleo-crinoidea of America. Crinoids, lovely ones, were abundant in the bluffs south of Burlington, and many times my father and I chipped them out with a geologist's pick. I gave Professor Trowbridge some, and he gave me a B in the course. I felt I deserved a higher grade (what student doesn't?), but I was not dissatisfied, for the course opened my eyes to a whole new world of glaciation, igneous rock, and even primitive cultures of primitive men. I was tempted to become an archeologist. I read Heinrich Schliemann on the excavation of ancient Troy and dreamed of leading an expedition to Mycenae.

It was far more exciting to imagine myself in desert shorts and pith helmet supervising a dig which might uncover ancient bones or burial 
treasure than it was to face campus reality clad in military uniform and doing close-order drill in order to satisfy requirements for what then was called military science. The wool uniforms itched, and I could never seem to wrap yards of khaki cloth around my legs in proper fashion. I never felt a sudden surge of military might when I presented arms with a wooden rifle. I reacted in much the same way to physical education, which to me was only an ill-defined set of upsand-downs whose ultimate purpose was to force one into a shower stall as quickly as possible.

However, if I did as little as possible with the university's corps of conscripts and if I wrangled a physician's excuse which separated me from the "one, two, three, and bend" of the physical education torturers, I did relish my French classes. I speculated that the language might assist me when as an archeologist I might need a universal tongue and might even, so raced my youthful imagination, be forced to sit in a sand-bound cantina and chat with heroes of the Foreign Legion. So I bent with a will to the French. As an assignment, I translated the story of Peter Rabbit, but even then I was unsure whether or not the adventures of Pierre Lapin would fascinate battlehardened legionnaires. I also read an American history in French. I may add, somewhat parenthetically, but not with any hostility, that my French instructor (his name is not listed on my transcript) was a corn-fed Middle Westerner who affected the patina of a Parisian.

I was sort of a maverick, following my own rugged trail and not particularly caring where the main herd of freshmen was driven either academically or socially. I made many acquaintances, but few friends. In spare time I took my geologist's pick, went on shank's mare to Coralville to dig on the fringe of the terminal moraine, or, sometimes just wandered the Iowa City streets to window shop or buy a book or two, although there was nothing in town like a real bookstore. The general ambiance of downtown Iowa City seemed more attractive, in a sort of bucolic fashion, a half-a-century ago than it does now.

Toward the middle of the second semester, although I was happy enough and although I realized I was receiving a solid education and had learned much, I decided, after a conference with my parents, that I wanted to transfer to Northwestern University. Other members of my family had graduated from there. Then too, I had friends who constantly sang the praises of Evanston and Chicago.

They emphasized the advantages of a large city-many bookstores, a superior university library, and musical and other cultural advantages. They told me that their professors actually invited students to visit with them and not infrequently took them into their homes. These 
friends, more efficient than many a college recruiter, promised to pledge me to a fraternity the minute I decided to transfer-before I ever set foot on the Evanston campus. I fell easily into the tempter's clutch. I looked forward to living with close friends in a fraternity house.

Perhaps, although I am not absolutely certain, a fire in my roominghouse was a tiny, but brilliant, factor which helped tip the scale. One evening while the graduate students in psychology were closeted in the bathroom for goodness knows how long, when the pharmacy students were drunk and fighting in their quarters, when the nurses on the ground floor were, as usual, entertaining boyfriends, the accumulation of newspapers in the girls' room caught fire. I never knew how the blaze began, but always supposed it was from a cigarette. The girls believed my shouts of alarm were only a ruse to hurry them out of the bathroom so I could use it. The pharmacy students didn't or' wouldn't hear the pounding on their locked door. The nurses wouldn't open up. The deaf landlady couldn't hear me. So I called the fire department. Damage was slight, but the landlady was outraged and promptly evicted all her roomers except me. I clearly remember all this because it was the first alarm I ever turned in. Indeed, I've turned in only two. The second was in New York City in the apartment of Professor Thomas Ollive Mabbott, distinguished Poe scholar, many of whose papers and books now are in the Special Collections of the University of Iowa Libraries. Incidentally, T. O. M. was my professor at Northwestern University as was Garrett Mattingly, who later wrote the excellent Catherine of Aragon and Invincible Armada and Elizabethan England.

I received both a bachelor's and a master's degree from Northwestern at the end of four wonderful, stimulating, exciting, and never-to-beforgotten years. During the early depression period, I taught at a submarginal institution, Long Island University, Brooklyn, New York, until the failing economy practically closed the institution. My colleagues and I were severed with several months of back salary unpaid. I married just before receiving my terminal notice.

Marion and I, with little money and no prospects of a job, fled from Brooklyn to Burlington. En route, we made the decision to enter graduate school at The University of Iowa. That had been my ambition since receiving the master's degree. Now, we both agreed, was the time to work toward a Ph.D. in history. We pooled our slight savings, borrowed on my insurance, and, with financial assistance from our parents, drove to Iowa City. Again it was autumn, the same kind of a September day it had been in 1923 when I left home to become a 
freshman. It was hot, windy, dusty. Withered corn stood in fields. Rogued corn lay on the ground. Cows lazed at pasture, swishing tails at flies. Hogs slept outside their houses. Roads were not much improved.

Iowa City had not changed perceptibly. It still was a small town with students idling on the grass outside Schaeffer Hall and Old Capitol. Farmers came to town to trade, and the Amish, in crowned hats and black suits, tied horse-drawn buggies to hitching posts. I felt much more at home than $\mathrm{I}$ ever did as a green freshman. Somehow there was a warmth, instead of a chill, in my bones.

We agreed that the best chance of entering graduate school was through an old Burlington friend, Ira Pierce, who, in 1933, was a research associate in pharmacology. Pierce, whom I first met in 1923 when he operated a clinical laboratory in Burlington, was a unique individual. Tall, well built, and with rather rough-etched features, he was both an excellent scientist and a man steeped in the classics. $\mathrm{He}$ spoke three languages and read five. He devoured just about any book in any field he could put hands on. He possessed a fine sense of humor tinctured with a dry wit. His great interest, aside from his research in morphine addiction, was the history of medicine. For years he gave such a course to medical students.

Pierce was related to Paul C. Packer, dean of the School of Education. His wife and Packer's wife were sisters. The thing to do, Pierce told us, was for him to take us to talk to Packer. When we arrived at Packer's office, Pierce, as I recall, said something like this: "These youngsters will make good. They are down and out. Phil has the makings of a good historian. He has published several articles. What can we do to help?" It was straight talk and to the point.

Packer picked up the telephone, called Carl E. Seashore, dean of the Graduate School, and, when he concluded the conversation, said to me, "You are admitted and you have an assistantship of $\$ 32.00$. Go over to the Dean's office and fill out the required forms."

Thirty-two dollars! Thirty-two dollars in September 1933! We were as thrilled as if we had just found the treasures in King Tut's tomb. Contemporary readers who did not suffer through the Great Depression may suspect that the drama played out in Packer's office was no drama at all and that our exhilaration over such a small sum is exaggerated. They are wrong on both counts. Those who experienced the rigorous hardships of the times will understand. My stipend for two academic years and one summer session totaled about $\$ 250.00$. Generally speaking, most graduate students whom I knew were in about the same financial straits as we were, and common poverty bound us 
together. My wife, again with the help of Pierce, found employment as a secretary in the Child Welfare Department. Evenings she typed master's essays and doctoral dissertations at ten cents a page.

We finally found a comfortable and reasonably priced apartment managed by Henry and Ruth Fisk. It was situated on Davenport Street near the University High School and so close to the waterworks that every time steam was released we jumped. The apartment was furnished with cast offs from my parents. Henry, an architect, and Ruth, his wife, became close friends with us. Henry's father for years was the University's superintendent of grounds and buildings. We played bridge with the Fisks, went once every two weeks to a tavern which sold a fishbowl of beer for ten cents, and, now and again, made short trips together. Years later, after Henry's untimely death, Ruth joined us when I lectured in Yugoslavia and also traveled with us to the South Pacific.

Although at Northwestern University I concentrated on European culture, European intellectual history and modern European history, my interest gradually turned to United States history. Two areas attracted me. One was social and intellectual history and the second was the trans-Mississippi West. My appetite for the latter was whetted by research done for my master's essay, a history of the Hawk-Eye and the Gazette, two Burlington newspapers.

During the search for material I became acquainted with the role played by Dr. William Salter, pastor of the Burlington Congregational Church for 60 years. A member of the famous Andover Band which arrived in Iowa in 1843 to preach the Gospel and to establish Grinnell College, Salter was both an outstanding churchman and an historian. Long before I entered graduate school at Iowa, I located and received permission to use a large collection of Salter manuscripts, letters, diaries, journals, and account books. I thought a biography of Salter might be proper for a doctoral dissertation.

I talked the project over with Professor Winfred T. Root, my adviser and head of the history department. Root, not too tall and of medium build, customarily, as I recall, wore salt-and-pepper suits. To me he also seemed to wear an expression of slight bewilderment, although he could be forthright enough. When he could manage itwhich was frequently-he invited his graduate students across the street for coffee and a "conference." Actually, the nub of the conversation centered on a book on colonial history which Root said he was writing for an outstanding publisher. The text never appeared while I was in graduate school, and I never learned of its publication subsequently. 
Anyway, Root, a colonial historian, approved a dissertation which properly belonged in Professor Louis Pelzer's field, for he taught frontier history and certainly Salter was a frontiersman. Perhaps Root agreed to take me on because he was happy to have a ready-made topic suggested and thus did not have to think about a proper topic in his specialty. More likely, he blessed my idea because he was stealing a student from Pelzer. I tactfully-and timidly-suggested that perhaps Pelzer was the man with whom I should work, but Root merely shrugged.

Fortunately, in good old army fashion, before I chatted with Root about Salter, I protected both my flanks and my rear. I talked with Pelzer before I faced Root. Pelzer accurately predicted what would happen, but he assured me that he would supervise both my research and writing even though technically I was Root's protégé. All this was my introduction to a rift within the department. A plan was afoot, as many graduate students learned and as Professor W. R. Livingston said, to eliminate Root as department head. ${ }^{2}$ The coup failed, but there was a lot of trouble in the department. Fortunately, I walked the tightrope successfully and whitewashed both sides of the fence. Root was always more than gracious, and Pelzer always more than helpful.

I carried two of Root's offerings in colonial history, one a lecture course and the other a seminar. He began the former, according to notes I consult as I write this, by saying that the colonial era was significant because it was a part of the founding and expansion of the British Empire, because it was the story of the founding of a new nation in America, and because "it is the story of the development of the individual evolution of each colony, from colony to state, each as the result of the demand and opportunity for self-expression." He warned that students must control the tendency "to glorify the era as the golden period in our history, as if our forefathers were consciously trying to work out a brilliant program." The colonial era, Root insisted, "is not the golden vestibule to American history. The method was trial and error, and the human element involved was not comprised entirely of infallible statesmen."

Students were requested to read E. B. Greene, Foundations of American Nationality; M. W. Jernegan, American Colonies; Edward Channing, History of the United States; and, among others, Oliver P. Chitwood, A History of Colonial America. Later Root added such titles as J. A. Doyle, British Colonies in America; Preserved Smith, Age of the Reformation; and J. A. Doyle, English Colonies in America.

2 Beilman interview with Livingston. 
By the close of the second semester, Root, after peopling the Atlantic seaboard, discussing the colonial merchant, describing social life in the colonies, and outlining both political and economic ties with England, closed with a discussion of events both in the mother country and the colonies which resulted in the American Revolution. He assigned some readings on the War for Independence. Unfortunately, I have no recollection of Root's seminar, nor do my files hold notes, bibliographies, or outlines for oral reports.

I also took two courses from Professor Harrison J. Thornton. They were American Social and Cultural History and the History of the South. Thornton, placid on the surface, inwardly boiled with a passion and was consumed with an interest in the history of Chautauqua, a semi-educational movement which not only held summer sessions in Chautauqua, New York, but also conducted home-study groups by mail and sent scores of lecturers, politicians, singers, and bellringers throughout the nation to perform in small towns.

Thornton's courses were carefully patterned. When lecturing, he held his students' attention. But, like Root, he seldom, if ever, sent students to primary documents. He was fond of assigning various volumes in the series "A History of American Life," and we read, for example, Thomas J. Wertenbaker, The First Americans, 1607-1690, and James T. Adams, Provincial Society, 1690-1763. When he introduced me to John B. McMaster, History of the People of the United States, I was fascinated and compiled a set of quotations about six inches thick, many of which I later used when I taught. Thornton also called my attention to an older set, Seymour Dunbar's A History of Travel in America. In Dunbar I found my first reference to the National Road, and I later wrote a book about that great highway. ${ }^{3}$

Somehow, Thornton's course in southern history, although it should have been exciting, turned out to be little more than informative. In all fairness, however, it should be pointed out that southern history was just about out of its babyhood in the early 1930s, although it was maturing rapidly. The Journal of Southern History, for example, did not begin publication until 1935. Nevertheless, Thornton recommended reading what he thought were beneficial books. I read with both pleasure and profit Gilbert H. Barnes, The Antislavery Impulse and the two volumes of John Fiske, Old Virginia and Her Neighbors. Neither would be on a reading list today. Had I taken the course about a year later, I know I would have profited from William B. Hesseltine's A

3 Philip D. Jordan, The National Road, The American Trails Series (Indianapolis: The Bobbs-Merrill Company, 1948). 
History of the South, 1607-1936, but the volume was not published until my graduate career was over. Thornton did not give as much emphasis to the New South as did Hesseltine. To his everlasting credit, Thornton paid due attention to the impact of the Mexican War on the South, urging his students to read Justin H. Smith, The War With Mexico, and George L. Rives, The United States and Mexico, 18211848. There were newer and better studies, but Smith and Rives were sufficient for those just being introduced to the impact of the war on the South. The course was no waste of time. It should be added, somewhat parenthetically, that Thornton's huge manuscript on the Chautauqua movement never was published.

Although I generally was pleased and gratified with instruction received from all my professors, I learned more from Pelzer than from any of the others. I still hold him in deepest esteem. He was not always easy to get along with. At times he was as formidable as a bear with a thorn in his paw. Tall, well built with craggy features, he, at times, froze students by merely looking at them. He possessed the facility of finding the weakness in an oral report or written paper and fairly sizzling the author with sarcasm. When he assigned seminar readings, students raced one another to the library to be first to gain access to the references.

But once Pelzer knew you and you learned to know him, he was a different individual-helpful, sympathetic, understanding, soft spoken. But even then he never pulled his punches. He was both curt and courteous. Lazy students were doomed. A somewhat unhappy man, his students, I always felt, were to a great extent his family. No doubt the loss of an arm affected his personality. Certainly, the death of two sons during military service left its imprint. Nevertheless, Pelzer, at times taciturn and on other occasions loquacious, was ever eager to be of service to serious students. Sometimes a deep, hidden well of humor bubbled to the surface. He loved to listen to stories and to tell them. Nothing, I believe, tickled him more than to sprawl on a bed in a hotel room, drink in hand, at a meeting of the old Mississippi Valley Historical Association and swap tales, most of them inappropriate for the classroom.

Pelzer's seminar put heavy emphasis upon root documents. One learned the history of the developing West from documents in the Serial Set, not from secondary sources, although he was happy if we read widely. He was death on standard texts, caustically characterizing them as "outward signs of an inward disgrace." He liked his students to draw maps, and I think I drew on the backs of shirtboards all the trails from the Wilderness Road to the Chisholm. When, in 1934, he 
with the assistance of Charles H. Norby and Walker Wyman, both his students, saw the publication of A Topical Guide to the Mississippi Valley Historical Review, Pelzer flourished a copy with a triumphal gesture. That was one way of underlining the importance of reading journal articles. "Build your writing on documents," he said. He used both journal articles and documents when writing his The Cattlemen's Frontier, his major work, published in 1936. Instead of autographing my copy, Pelzer presented me with a half sheet, reading, "Louis Pelzer, 226 Schaeffer Hall, University of Iowa." That, he said solemnly, could be inserted in the volume without "spoiling" the book. He relished doing things differently.

Some years after receiving my Ph.D., when Pelzer was editing the Mississippi Valley Historical Review, he invited me to edit the Teachers' Section. As usual, he was strict and held me to high standards. Yet, when I completed my editorial term, he wrote on February 1, 1943: "This is a belated note of appreciation of the fine work you have done in editing the Teachers' Section. ... Your part in the book reviews, notes, and news notes has added considerable life to that part of the magazine, and I believe will so strike the brethren of the faith."

It was Pelzer who suggested a book for me to evaluate for the Review. The length of the review was to be 150 words. Pelzer made me write that review in exactly that number of words, including "ands" and "ifs." Pelzer also saw to it that my first article published in the regular columns of the Review met his criteria. I disremember how many times I wrote and rewrote that piece, but when it appeared under the title of "Humor of the Backwoods, 1820-1840" in the June 1938 issue, Pelzer, with a broad grin, judged it "tolerable." That was about equivalent to receiving the Star and Garter.

There is another incident which deserves a place in these relations. One summer, when I was teaching at Miami University in Ohio, Pelzer invited me to take his classes while he was absent. I was to offer a course in the history of the West and was to live in his house. In his invitation Pelzer indicated strongly that I was not to think I knew everything and suggested it would be well if I used Harper's Encyclopedia, which he kept on a shelf in the kitchen. About the first thing I did when we moved in was to find that invaluable reference, although for the life of me I could not understand why Pelzer should recommend it. But there it was-not a set of books, but a bottle of Harper's bourbon.

Thanks to Pelzer and Pierce, I received annual research assistantships. In addition to reading papers, gathering material for Pelzer, and keeping up my seminar obligations, I devoted time to the researching 
and writing of my Salter biography and managed to publish in various journals. Before entering graduate school, I placed articles in the Journal of the Illinois State Historical Society, Annals of Iowa, Ohio Archaeological and Historical Quarterly, American Literature, and even in The Quill, American Journal of Nursing, and Field and Stream. I reviewed regularly for Social Science Abstracts. During graduate school days, I contributed to periodicals such as The New Viewpoint and The American Book Collector. In 1935, the year I received my doctorate, two articles were printed in the Iowa Journal of History and Politics and one each in Annals of Iowa, The Palimpsest, Social Science, The Advance, and the Bulletin of the New York Public Library. Biographical sketches of William Salter and his son, William Mackintire Salter, appeared in the Dictionary of American Biography.

All this would have been impossible had it not been for the assistance and encouragement not only of those with whom I took classes but also of those members of the department with whom I carried no courses. All were kindly men. My best friend outside the department was Pierce. He spent an evening at our apartment at least once a week. We talked both of my projects and of his. Discussion might center on vegetable dyes, on army medicine during the American Revolution, on Theodore Miller's Pioneer Medicine in Western Pennsylvania, on departmental in-fighting, on new slides which Pierce was preparing for his course in the history of medicine, on steamboating, or on rural life in Blairstown, Iowa, where Pierce was born. We talked of rivers and rivermen and of mountains and mountain men. One evening we hit upon the idea of doing an article together.

Somehow or other, Pierce had found diaries and papers of a seafaring physician who, as a United States Naval Surgeon, practiced during the middle decades of the nineteenth century. Dr. Lewis A. Wolfley in 1835 requested leave to study medicine in Paris. He kept a daily account of his work with distinguished French physicians at the Hôtel Dieu, the École de Médecine, and the Hôpital de la Charité. Unfortunately, Pierce found himself too occupied to help transcribe the manuscript and turned the project over to me. "A Naval Surgeon in Paris, 1835-1836" was published in three parts in Annals of Medical History beginning in November 1940.

Professor George G. Andrews, with whom I took no work, was another frequent visitor. A European historian with a special interest in the French Revolution, Andrews was acquainted with Professor Leo Gershoy who was a friend of Professor Mattingly and of Mabbott. When Andrews learned that I knew Gershoy and helped Leo read galley proof on his The French Revolution and Napoleon, he intro- 
duced himself. Soon we were friends. We fished together in the Iowa River, but caught nothing but a plague of chiggers. We swapped books. We traded departmental gossip. Andrews, I recall, was not fond of Root as a department head. He admired Pelzer, but thought him at times a "strange" fellow.

When Andrews spent an evening with us, the talk was mostly of historical method and the philosophy of history. We both wished that the department offered courses in those areas, although, as Andrews said, boundless breath could be wasted when attempting to define history. One time Andrews came stalking in with two green-bound books under his arm. "Here," he announced, "you must read these. But first I want you to hear this." The volumes were Jean J. Jusserand and others' The Study of History and Allen Johnson's The Historian and Historical Evidence, and the passage he read was from the latter. "You ought to hear this if you are writing a biography," he said. Then he began:

At the risk of tiresome reiteration, it may again be said that the historical student should be on his guard against the motivation of biographies and histories. No rapid skimming of a preface will suffice, for the author is often sublimely unconscious of the tendency or bias which may vitiate his historical work. On the other hand, this bias may itself be an historical fact of some importance. A biography written while the memory of a great personage is still green may bear strong testimony to the charm of his personality, even though it exaggerates his part in the history of his times and distorts a whole sequence of events.

Andrews also drew my attention to Langlois and Seignobos, Introduction to the Study of History, and I well remember new terms added to my vocabulary-epigraphy, sphragistic, heuristic.

I was not aware of it, but Andrews was preparing his article, "The Use of Historical Sources," which he published in The Social Studies, November 1936. He sent me a reprint, and I still treasure it. He wrote, in part, what he had told me: "One of the most important uses of sources is to impress upon the student the fact that history is based upon evidence. History is not the product of an uncontrolled imagination, of the idle fancy of some dreamer, invented for his own or others' amusement." The foundation of all history, he maintained, is found only in sources. "No sources, no history." Andrews, during our conversations, also spoke of the scholar's need for self-discipline, warned that research at times was tiresome, and spoke of the necessity of culling, selecting, choosing, and rejecting. 
Livingston was another with whom I had no formal work, but who, in his broad hat and booming voice, became a friend and offered invaluable advice. Now and again he invited me to his house for a cup of cheer and a large measure of practical wisdom. He loved to tell tales of his experiences as a Missouri farmer. Energetic and resourceful, he was filling the library with official documents from England and her colonies. His ambition, as he later said, was to establish a Bureau of Foreign Relations at the University and "bring to this campus all the published documents from every government in the world."4 Like Pelzer and Andrews, Livingston was dedicated to the importance and use of primary sources. Once, while chatting about the utility of them, he casually mentioned the wonders to be found in the American State Papers. They were new to me. The next day I hotfooted to the library and in the document room discovered what Livingston said was true. I have always been indebted to him.

If the economic recession curtailed our living style, it caused no depression in the intellectual world. Graduate life, at least in the history department I knew, was both healthy and prosperous. Always there was spirited and lively conversation. Financial losses were offset by intellectual dividends. At least, I found it so. Of course, there was an underlying urgency, a knowledge that I must get that degree as soon as possible in order to find a job with a decent salary, but such worries did not cloud the happiness which graduate study provided.

Food might be expensive, but talk was cheap, and we were extravagant with it. I recall, for example, a long discussion held in our apartment about history as confrontation. We were saying that men, like negative and positive charges, both repel and attract one another, but that no laws of harmony prevailed, so that individuals and nations were frequently in disagreement and at one another's throats. Pierce offered his opinion that war is a natural phenomenon and always would exist as a normal pattern in both organized and unorganized societies. Andrews tended to agree. $\mathrm{He}$ argued that confrontation is only one phase of the process of the survival of the fittest. Both Pierce and Andrews took a dim view of the validity of any spiritual interpretation of history. They, as I remember, saw selfish nationalism as a far more potent force than any divineness of gods or men. That does not imply or infer that the debaters were either agnostics or atheists, although neither found fault with the deism of the Founding Fathers.

Talk flowed where it would. One evening was devoted to discussing internal and external evidence. Another time the subject was the So-

4 Beilman interview with Livingston. 
cratic method. I was prodded and probed about the progress of my Salter biography. Was the completed dissertation to be a bit of local history, an exercise in antiquarianism, of Clio's fossilogy? Could I successfully place the home missionary in the ambiance of his times? What were the characteristics of the Iowa frontier in the 1840s? How trustworthy were the quarterly reports sent by Salter and his colleagues of the Iowa Band to the American Home Missionary Society? Pelzer asked bluntly, "Will anyone besides you and me ever read the book? Are you writing it so that it has life and liveliness and still tells the truth?" All in all, informal evenings were just about the best seminars I ever attended. My hastily scribbled notes bear evidence of that, and I am pleased I preserved them.

Perhaps the real pilot, if not the captain, of the department was Miss Veva Cox, departmental secretary. To generations of graduate students she was a friend, a buffer, a mother confessor, a counselor, and adviser. She knew the feuds, and, when necessary, signaled heavy storms and shallow shoals. She was acquainted with the staff's idiosyncrasies and peccadilloes. Best of all, she was so well-liked by other departmental secretaries that she need only to pick up the telephone to secure information that a graduate student would find difficult to obtain.

Miss Cox introduced me to some staff members of the State Historical Society of Iowa. Professor Benjamin F. Shambaugh looked down his red silk necktie and apparently decided he saw nothing of interest. Ruth A. Gallaher quizzed me at length about Salter, indicating that she might be interested in my writing an article about him for her Iowa Journal of History and Politics. John Ely Briggs warmly welcomed me and showed me the society's library. Although I never thought of Miss Gallaher as a warm person, she was a competent editor of the Journal and greatly aided me when I wrote my "William Salter and the Slavery Controversy." Under her direction, the Journal was among the outstanding state publications in the nation. Later I became a firm friend of Mildred Throne, a lovable person, competent historian, and excellent editor of the Journal.

Briggs, editor of The Palimpsest, was to me an outgoing, affable, talented individual with no acidity or tartness in his makeup. He had an almost uncanny ability, it seemed to me, to select historical topics which appealed to his readers. He insisted that articles in The Palimpsest be based upon sound sources. I remember how, when I submitted my "The Iowa Pioneer Phalanx," Briggs sat down with me to point out patiently where the manuscript might be improved, and, to my embarrassment, found errors of fact. How grateful I was. Briggs him- 
self wrote well. His many articles in The Palimpsest and his William Peters Hepburn are testimony to that.

Although Shambaugh, after he became aware of me, would swing his walking stick in my direction in greeting, he always impressed me as somewhat of a showman. It was easy for me to picture him hawking Dr. Jacob's Liniment, good for men and animals, in a small town from the rear end of a wagon. Such an image was, of course, most unfair. I was not unaware of Shambaugh's contributions both locally and nationally. He was a member of the group which founded the Mississippi Valley Historical Association and was active for many years. I used to observe him holding court at annual meetings. Pelzer and others respected Shambaugh's policy of publishing documents such as the Messages and Proclamations of the Governors of Iowa, the Executive Journal of Lowa, 1838-1841, the Applied History Series, and biographies of the governors. Such a program results not in ephemera, but in substantive volumes as useful today as when they appeared. Shambaugh, with his lecture series and other activities, contributed much to the campus.

Although I did not quite put it all together when a graduate student, now, almost half a century later, I discern a pattern: almost all with whom I came in contact were preoccupied with primary sources and documentation. Records were a sort of obsession, a characteristic which I failed to notice when a graduate student at Northwestern University. My only two professors on the Evanston campus, as I recollect, who impressed students with the value of original source, were James A. James, author of a biography of George Rogers Clark, and William V. Pooley whose The Settlement of Illinois from 1830 to 1850 taught me many a lesson.

Athough I took no courses in journalism at Iowa, I came to know Frank Luther Mott well. Head of the School of Journalism, Mott was interested, as was I, in the history of printing. My interest originally stemmed from Tom Mabbott's collection of incunabula, books printed before 1500. I could not afford such expensive items, but I found I could purchase at reasonable prices broadsides and funeral sermons, including a few printed by Isaiah Thomas, printed during the eighteenth and nineteenth centuries. One crisp afternoon, I took samples of my collection to show Mott. He, in turn, opened his files of notes compiled for his first volume of A History of American Magazines, so I learned something of his research technique. During the conversation, Mott mentioned two titles he believed would interest me. The first was Lucy M. Salmon, The Newspaper and the Historian. The second was Isaiah Thomas, The History of Printing in America. I should 
have known about the latter. I borrowed both books from the library and was so impressed by Thomas that I wrote the American Antiquarian Society, the publisher, to see if perchance the 1874 edition was still in print. It was, and I purchased a copy. It was my birthday gift to myself.

Meanwhile, the dissertation's final draft was edited and revised. I passed the French examination easily and continued to labor on the German. Professor Erich Funke offered a special course designed to prepare candidates for the German ordeal. Those were the days when Ph.D. students were forced to qualify in both French and German. I wanted to substitute Spanish for German, not because it is alleged to be an easier tongue, but because I thought it would serve me better if I continued an interest in the West, especially the Spanish Borderlands. But that proved impossible. The German course started with a goodly number of students. When it ended, there were only a relatively few. Funke, realizing that many of us were taking the course only because we were obliged to, seemed to make it as difficult and unpleasant as possible. At least, that's what we believed. I managed to squeak through.

That hurdle leaped-perhaps it would be more accurate to say crawled over-I carried copies of the Salter manuscript to both Root and Pelzer. Each promised to read it promptly. The manuscript was long and both footnotes and bibliographic essay comprehensive. Root returned it three days later with no comment but that it was well done. Pelzer kept it about two weeks. When I walked into his office to pick it up, I noticed not only the dissertation but also a pile of pink slips which looked about as thick as the biography itself. My God, I remember thinking. Is it as bad as all that?

Pelzer searched me with penetrating eyes. I cannot recall his exact words, but I'll never forget the gist of the conversation.

"Do you think you did a creditable job?" Pelzer slapped his one hand on the stack.

I cannot reconstruct my reply, but I stammered something.

Pelzer grinned. "I've got about a dozen items for you to check. That's all."

"What about those other slips?" I asked.

"Oh, those notes are something else. I put them there to see what you would do."

That is an example of Pelzer's puckish pranks, his sense, shall we 
say, of humor, but he swore he only "joked" friends. ${ }^{5}$ I went home, as the bromide goes, on the wings of angels.

All that came afterwards was anti-climactic-the retyping of a few pages, the tense days of reviewing in preparation for the orals, the packing of books and household items, and, finally, the oral examination in Old Capitol. When that pleasant session concluded with the customary handshakes and congratulations, I, to all intents and purposes, was a Doctor of Philosophy in History. I would not say I was an historian, for my education was just beginning.

5 For additional comments on Pelzer, see Philip D. Jordan, "Louis Pelzer: Scholar, Teacher, Editor," Mississippi Valley Historical Review, 33 (Sept. 1946), pp. 211-16. 